\title{
Use of oral contraceptives for management of acne vulgaris and hirsutism in women of reproductive and late reproductive age
}

\author{
Radosław Słopień, Ewa Milewska, Piotr Rynio, Błażej Męczekalski \\ Department of Gynecological Endocrinology, Poznan University of Medical Sciences, Poland
}

\begin{abstract}
Hormonal contraception in both reproductive and late reproductive age, as well as contraceptive action, is used also for other indications like dysmenorrhoea, menstrual disorders, endometriosis, acne vulgaris, and hirsutism. Acne vulgaris and hirsutism are important signs related to hyperandrogenaemia and present a serious medical problem for the patients and a challenge for medical doctors in terms of effective treatment. The application of hormonal contraception to treat acne vulgaris and hirsutism requires knowledge of the mechanism of antiandrogenic actions and the possible contraindications and complications. These data are presented in this review.
\end{abstract}

Key words: hormonal contraception, acne, hirsutism.

\section{Introduction}

Hormonal contraception, as well as contraceptive action, is used also for other indications like dysmenorrhoea, menstrual disorders, endometriosis, acne vulgaris, and hirsutism [1]. According to epidemiological data, hirsutism affects 5-15\% [2] and acne affects 6-55\% [3] of the female population. Both hirsutism and acne are signs of hyperandrogenaemia [4] but are not always related to abnormal hormonal background [5]. Among the causes of hyperandrogenaemia polycystic ovary syndrome, hyperthecosis, adrenal hyperplasia, obesity, Cushing syndrome, androgen secreting ovarian and adrenal tumours, and liver insufficiency are reported [4]. These are related to increased androgen synthesis or impaired androgen inactivation. Although the pathogenesis of acne and hirsutism is multifactorial, it is usually related to the intracrine synthesis of active androgens in the skin. Sebaceous glands and hair follicles act as independent endocrine organs and respond to the different levels of androgens [6-8].

The androgens synthesised by adrenal glands and ovaries are converted in enzymatic reactions in sebaceous glands and hair follicles into dihydrotestosterone (DHT). Dihydrotestosterone is 5 to 10 times more potent androgen receptor agonist than testosterone. DHT is synthesised from testosterone in the presence of $5 \alpha$-reductase [6]. Intracrine synthesis and possible oversensitivity of the sebaceous gland and hair follicles to androgens explains why the women affected by acne and hirsutism may have normal androgen levels [9].

\section{Hormonal contraception}

Hormonal contraception consists of combined hormonal contraception and progestin-only contraception. Combined hormonal contraception consists of two components: oestrogen and progestin, and is marketed in the form of pills, patches, and vaginal rings. Progestin only contraception is marketed in the form of pills, injections, intrauterine devices, and implants. Combined contraception may have a beneficial impact in the treatment of skin changes; progestin-only contraception may not help in the treatment of skin problems and may even worsen the state of the skin [10].

The oestrogen components of combined contraception are ethinyl oestradiol and oestradiol valerate. The oestrogen content of the contraceptive combined pill is very small in relation to the oestrogen content of the pills produced in late 1950s and 1960s. The decrease of oestrogen compound caused an increase of the importance of the progestin compound [11].

Progestins in contraceptive pills may be divided into two groups: 17-OH progesterone derivates and 19-nortestesterone derivates. Among $17-\mathrm{OH}$ progesterone derivates nomegestrol, medroxyprogesterone acetate, cyproterone acetate, and chlormadinone acetate are used. Among 19-nortesterone derivates there are three generations that differ in relation to antigonadotropic, progesteronic, and androgenic properties [12]. Firstgeneration progestins have both progesterone and androgen receptor affinity, while second-generation progestins are more progestagenic and less androgenic. 
Third-generation progestins are strong progesterone agonists with even less androgenic activity. Typical first- and second-generation progestins used in clinical practice are norethisterone and levonorgestrel respectively. Third-generation progestins include norgestimate, gestodene, and desogestrel. Also there are also so-called fourth-generation progestins, designed to be without androgenic properties. The first of these is drospirenone, which is an antimineralocorticoid spironolactone derivate [13]. The second is dienogest, which is structurally related to 19-nortestesterone [14].

\section{Late reproductive age and combined contraception}

Combined contraception may be used in women in late reproductive age without smoking, hypertension, and BMI higher than $35 \mathrm{~kg} / \mathrm{m}^{2}$. In this group, higher risk of cardiovascular disease and brain stroke should be kept in mind. In these women the lowest dose of ethinyl oestradiol should be chosen. Apart from effective contraception, these pills may ameliorate irregular menses, heavy bleedings, climacteric symptoms, and bone density loss [11].

Hirsutism and acne may occur for the first time or aggravate in late reproductive age. This phenomenon is related to decrease of oestrogen level and no change in androgen secretion [10].

\section{Oral contraception: mechanisms of antiandrogenic action}

Antiandrogenic properties of combined contraception are related to both components of the pill: oestrogen and progestin. Oestrogen stimulates sex hormone binding globulin (SHBG) liver synthesis that in turn reduces the amount of biologically active androgens, induces oestrogen receptor expression, and decreases gonadotrophin secretion that inhibits LH-related testosterone production by theca cells in the ovaries [15]. Progestins block $5 \alpha$-reductase activity, and decrease testosterone receptor expression and gonadotrophin (FSH, LH) synthesis [11]. $5 \alpha$-reductase is responsible for the conversion of testosterone into DHT. Both components of combined contraception lower the levels of adrenocorticotropic hormone (ACTH) that in consequence has inhibitory effect on adrenal androgenesis (dehydroepiandrosterone and dehydroepiandrosterone sulphate production) $[16,17]$.

\section{Results of clinical studies}

The progestins of documented antiandrogenic activity are as follows: levonorgestrel, norethindrone acetate, norgestimate, chlormadinone acetate, drospirenone, dienogest, and cyproterone acetate [1].

Cyproterone acetate ( $2 \mathrm{mg}$ of cyproterone acetate and 0.35 of ethinyl oestradiol) after 3 months of treatment caused subjective improvement in hirsutism in $83 \%$, improvement in trichoscopy in $77 \%$, visible improvement in acne in $40 \%$, and very good cosmetic effect in $26 \%$ of patients. $86 \%$ of patient finished the study, which suggests very good compliance and tolerability [18]. In a comparative study cyproterone acetate showed the stronger antiandrogen activity than drospirenone after 12 months of therapy (there was no difference after 6 months of therapy) [19].

Chlormadinone acetate ( $2 \mathrm{mg}$ of chlormadinone acetate and $0.03 \mathrm{mg}$ of ethinyl oestradiol) was effective in the treatment of mild to moderate acne and hirsutism [20], caused visible improvement in hirsutism and seborrhoea after 12 months of treatment [21], improvement of acne after 3, 6, and 12 months of treatment [22], and a relevant decrease of percentage of patients suffering from acne from $46.5 \%$ to $14.9 \%$ after 13 cycles of treatment [23]. Chlormadinone acetate reduced the number of patients with skin problems $(-55 \%)$, reduced the number of patients seeking dermatological treatment $(-67 \%)$ and concealer cosmetics $(-55 \%)$ and the number of patients who felt that their self-esteem was restricted due to skin problems (-67\%) [24]. Chlormadinone acetate was more effective in the treatment of acne than levonorgestrel [1] and was more antiandrogenic than dienogest [25].

Drospirenone (3 $\mathrm{mg}$ of drospirenone and $0.02 \mathrm{mg}$ of ethinyl estradiol) caused improvement in acne after 6 months of treatment [26], significant improvement in the trunk acne (improvement > 50\%) after 6 months of treatment [27] and significant reduction of skin problems treatment costs [28]. Drospirenone was more effective in the treatment of acne than norgestimate [1]. Drospirenone was more effective than chlormadinone acetate in the treatment of skin changes such as seborrhoea, acne, increased hair, hydration, homogeneity, and overall quality of the skin [29].

Dienogest significantly improved acne in $52 \%$ of treated patients in one study [30] and in $66 \%$ of treated patients in another one [31] and its antiandrogenic properties were also seen in a meta-analysis of 56 clinical studies (2266 women treated) [32]. Dienogest was more antiandrogenic than both drospirenone and chlormadinone acetate [25].

\section{Adding antiandrogen to oral contraceptives}

Adding an antioestrogen to an OC can be considered when initial response to 6 months of OC monotherapy has been inadequate. Available antiandrogens are following: spironolactone (aldosterone and androgen re- 
ceptor antagonist; the mechanism of its action is based on the competition with DHT for binding to the androgen receptor and inhibition of enzymes involved in androgen biosynthesis), cyproterone acetate (CPA - is a 17 hydroxyprogesterone derivative which competes with DHT for binding to the androgen receptor and reduces serum LH and ovarian androgen concentrations) [33].

\section{Oral contraception safety}

The real nightmare for every clinician is a serious adverse event during therapy. From time to time medical journals report a complication that is possibly related to the use of oral contraception. One of them was brain stroke in a 23-year-old fitness trainer after 3 weeks of oral contraception because of acne [34]. The patient used $2 \mathrm{mg}$ of cyproterone acetate and 0.35 of ethinyl oestradiol and had no other risk factors of thrombosis. She was diagnosed with nonfluent aphasia and fully recovered after thrombolytic treatment.

\section{Oral contraception and the risk of thrombosis}

Oral contraception increases the risk of thrombosis. The risk of thrombosis is highest during the first year of use [35], and it depends on the dose of ethinyl oestradiol and the type of progestin used. Cyproterone acetate use is related to the highest risk of thrombosis: relative risk of thrombosis during cyproterone acetate use is 6.35 (95\% Cl: 5.09-7.93) with number needed to harm per year (NNH) 890 [36], the relative risk of brain stroke is 1.4 (95\% Cl: 0.97-2.03); $\mathrm{NNH}: 44,643$ and relative risk of heart infarction: 1.47 ( $95 \% \mathrm{Cl}$ : 0.83-2.61); $\mathrm{NNH}: 303,951$ [37]. The relative risk of thrombosis during the use of norethisterone, levonorgestrel, and norgestimate is 2-3 with NNH: 2381-4762 [25]. Dienogest has a similar risk profile to levonorgestrel [38]. The relative risk of thrombosis during the use of desogestrel, gestodene, drospirenone, and contraceptive intravaginal rings was 4-6 with NNH: 952-1587 [39]. Chlormadinone acetate was reported to have a similar risk profile to desogestrel [40].

\section{Who should be treated with hormonal contraception}

Hirsutism and acne vulgaris may be symptoms of hormonal disturbances like polycystic ovary syndrome or adrenal hyperplasia. Idiopathic hirsutism is also a serious medical problem. In the case of hormonal disturbances the use of hormonal contraception not only improves the cosmetic situation of the patient but is also necessary to decrease the risks related to hyperandrogenaemia [41].
Hormonal tests are indicated in patients with acne resistant to treatment, in patients with hirsutism, and in patients with menstrual disorders. In this case, the following hormonal tests should be done: follitropin (FSH), lutropin ( $\mathrm{LH})$, total testosterone $(\mathrm{T})$, sex hormone binding globulin (SHBG), dehydroepiandrosterone sulphate (DHEAS), 17OH-progesterone, thyrotropin (TSH), and prolactin (PRL) [42].

\section{Contraindication to oral contraception}

According to WHO recommendations, the contraindications to oral contraception are as follows: pregnancy, breast feeding, history of deep venous thrombosis and thromboembolic event, active liver disease, smoking after the age of 35 years, migraine, breast cancer, hypertension, diabetes mellitus with vascular changes, and long-term immobilisation [43].

\section{Summary}

In summary the application of combined hormonal contraception in the treatment of acne vulgaris and hirsutism improves the cosmetic situation and should be considered as an effective option. This therapy should be applied after evaluation of the hormonal profile of the patient and exclusion of possible contraindications. In this setting hormonal therapy is relatively safe but possible serious complications should be discussed with the patient.

\section{Disclosure}

Authors report no conflict of interest.

\section{References}

1. Arowojolu AO, Gallo MF, Lopez LM, et al. Combined oral contraceptive pills for treatment of acne. Cochrane Database Syst Rev 2012; 11: 7.

2. Williamson D, Gonzalez M, Finlay AY. The effect of hair loss on quality of life. J Eur Acad Dermatol Venereol 2001; 15: 137-139.

3. Azziz R. The evaluation and management of hirsutism. Obstet Gynecol 2003; 101 (5 Pt 1): 995-1007.

4. Rosenfield RL. Clinical practice. Hirsutism. N Engl J Med 2005; 353: 25782588.

5. Karrer-Voegeli S, Rey F, Reymond MJ, et al. Androgen dependence of hirsutism, acne, and alopecia in women: retrospective analysis of 228 patients investigated for hyperandrogenism. Medicine 2009; 88: 32-45.

6. Labrie F, Luu-The V, Labrie C, et al. Intracrinology and the skin. Hormone Res 2000; 54: 218-229.

7. Lai JJ, Chang P, Lai KP, et al. The role of androgen and androgen receptor in the skin-related disorders. Arch Dermatol Res 2012; 304: 499-510.

8. Ebede TL, Arch EL, Berson D. Hormonal treatment of acne in women. J Clin Aesthet Dermatol 2009; 2: 16-22.

9. Thiboutot $D$, Chen W. Update and future of hormonal therapy in acne. Dermatology 2003; 206: 57-67.

10. Tyler KH, Zirwas MJ. Contraception and the dermatologist. J Am Acad Dermatol 2013; 68: 1022-1029.

11. Sitruk-Ware R Hormonal contraception and thrombosis. Fertil Steril 2016; 106: 1289-1294. 
12. Golobof A, Kiley J. The current status of oral contraceptives: progress and recent innovations. Semin Reprod Med 2016; 34: 145-151.

13. Rapkin AJ, Sorger SN, Winer SA. Drospirenone/ethinyl estradiol. Drugs Today (Barc) 2008; 44: 133-145.

14. Zhao Y, Ruan X, Wang H, et al. The presence of a membrane-bound progesterone receptor induces growth of breast cancer with norethisterone but not with progesterone: A xenograft model. Maturitas 2017; 102: 26-33.

15. Wiegratz I, Fink T, Rohr UD, et al. Cross-over comparison of the pharmacokinetics of estradiol during hormone replacement therapy with estradiol valerate or micronized estradiol. Zentralbl Gynakol 2001; 123: 505-512.

16. Rabe T, Kowald A, Ortmann J, et al. Inhibition of skin 5 alpha-reductase by oral contraceptive progestins in vitro. Gynecol Endocrinol 2000; 14: 223-230.

17. Zimmerman Y, Eijkemans MJC, Coelingh Bennink HJ, et al. The effect of combined oral contraception on testosterone levels in healthy women: a systematic review and meta-analysis. Human Reprod Update 2014; 20: 76-105.

18. Coneac A, Muresan A, Orasan MS. Antiandrogenic therapy with ciproterone acetate in female patients who suffer from both androgenetic alopecia and acne vulgaris. Clujul Medical 2014; 87: 226-234.

19. Bhattacharya SM, Jha A. Comparative study of the therapeutic effects of oral contraceptive pills containing desogestrel, cyproterone acetate, and drospirenone in patients with polycystic ovary syndrome. Ferti Steril 2012; 98: 1053-1059.

20. Guerra-Tapia A, Sancho Pérez B. Ethinylestradiol/Chlormadinone acetate: dermatological benefits. Am J Clin Dermatol 2011; 12: 3-11.

21. Kerscher M, Reuther T, Krueger N, et al. Effects of an oral contraceptive containing chlormadinone acetate and ethinylestradiol on hair and skin quality in women wishing to use hormonal contraception. J Eur Acad Dermatol Venereol 2013; 27: 601-608.

22. Schramm GA, Schrah G. The efficacy and safety of an oral contraceptive containing chlormadinone acetate: results of a pooled analysis of noninterventional trials in adult and adolescent women. Contraception 2011; 84: 390-401.

23. Pushparajah DS, Röhm P, Höschen K, et al. Safety data and beneficial effects of the combined oral contraceptive ethinylestradiol $0.03 \mathrm{mg} /$ chlormadinone acetate $2 \mathrm{mg}$ (Belara ${ }^{\circledR}$ ): a 13-cycle, observational study in routine clinical practice. Clin Drug Investig 2011; 31: 121-134.

24. Anthuber S, Schramm GA, Heskamp ML. Six-month evaluation of the benefits of the low-dose combined oral contraceptive chlormadinone acetate $2 \mathrm{mg}$ /ethinylestradiol $0.03 \mathrm{mg}$ in young women: results of the prospective, observational, non-interventional, multicentre TeeNIS study. Clin Drug Investig 2010; 30: 211-220.

25. Sitruk-Ware R, Nath A. The use of newer progestins for contraception. Contraception 2010; 82: 410-417.

26. Koltun W, Maloney JM, Marr J, et al. Treatment of moderate acne vulgaris using a combined oral contraceptive containing ethinylestradiol 20 $\mu \mathrm{g}$ plus drospirenone $3 \mathrm{mg}$ administered in a 24/4 regimen: A pooled analysis. Eur J Obstet Gynecol Reprod Biol 2011; 155: 171-175.

27. Palli MB, Reyes-Habito CM, Lima XT, et al. A single-center, randomized double-blind, parallel-group study to examine the safety and efficacy of $3 \mathrm{mg}$ drospirenone/0.02 mg ethinyl estradiol compared with placebo in the treatment of moderate truncal acne vulgaris. J Drugs Dermatol 2013; 12: 633-637.

28. Joish VN, Boklage S, Lynen R, et al. Use of drospirenone/ethinyl estradiol (DRSP/EE) among women with acne reduces acne treatment-related resources. J Med Econ 2011; 14: 681-689.

29. Lello S, Primavera G, Colonna L, et al. Effects of two estroprogestins containing ethynilestradiol 30 microg and drospirenone $3 \mathrm{mg}$ and ethynilestradiol 30 microg and chlormadinone $2 \mathrm{mg}$ on skin and hormonal hyperandrogenic manifestations. Gynecol Endocrinol 2008; 24: 718-723.

30. Di Carlo C, Gargano V, Sparice S, et al. Effects of an oral contraceptive containing estradiol valerate and dienogest on circulating androgen levels and acne in young patients with PCOS: an observational preliminary study. Gynecol Endocrinol 2013; 29: 1048-1050.

31. Palombo-Kinne E, Schellschmidt I, Schumacher U, et al. Efficacy of a combined oral contraceptive containing $0.030 \mathrm{mg}$ ethinylestradiol $/ 2 \mathrm{mg}$ dienogest for the treatment of papulopustular acne in comparison with placebo and $0.035 \mathrm{mg}$ ethinylestradiol/2 mg cyproterone acetate. Contraception 2009; 79: 282-289.
32. Borgelt LM, Martell CW. Estradiol valerate/dienogest: a novel combined oral contraceptive. Clin Ther 2012; 34: 37-55.

33. Swiglo BA, Cosma M, Flynn DN, et al. Clinical review: Antiandrogens for the treatment of hirsutism: a systematic review and metaanalyses of randomized controlled trials. J Clin Endocrinol Metab 2008; 93: 11531160 .

34. Kromm J, Jeerakathil T. Cyproterone acetate-ethinyl estradiol use in a 23-year-old woman with stroke. CMAJ 2014; 186: 690-693.

35. Arrington EA, Patel NS, Geranker K, et al. Combined oral contraceptives for the treatment of acne: a practical guide. Cutis 2012; 90: 83-90.

36. Lidegaard $\varnothing$, Nielsen LH, Skovlund CW, et al. Risk of venous thromboembolism from use of oral contraceptives containing different progestogens and oestrogen doses: Danish cohort study, 2001-9. BMJ 2011; 25: 343

37. Lidegaard $\varnothing$, Lokkegaard E, Jensen A, et al. Thrombotic stroke and myocardial infarction with hormonal contraception. N Engl J Med 2012; 366 2257-2266

38. Raps M, Rosendaal F, Ballieux B, et al. Resistance to APC and SHBG levels during use of a four-phasic oral contraceptive containing dienogest and estradiol valerate: a randomized controlled trial. J Thromb Haemost 2013; 11: 855-861.

39. Lidegaard $\varnothing$, Milsom I, Geirsson RT, et al. Hormonal contraception and venous thromboembolism. Acta Obstet Gynecol Scand 2012; 91: 769778

40. Winkler UH, Daume E, Sudik R, et al. A comparative study of the hemostatic effects of two monophasic oral contraceptives containing $30 \mu \mathrm{g}$ ethinylestradiol and either $2 \mathrm{mg}$ chlormadinone acetate or $150 \mu \mathrm{g}$ desogestrel. Eur J Contracept Reprod Health Care 1999; 4: 145-154.

41. Chan CS, Harting M, Rosen T. Systemic and barrier contraceptives for the dermatologist: a review. Int J Dermatol 2009; 48: 795-814.

42. Goodman NF, Cobin RH, Futterweit W, et al; American Association of Clinical Endocrinologists (AACE); American College of Endocrinology (ACE); Androgen Excess and PCOS Society (AES). American Association of Clinical Encocrinologists, American College of Endocrinology, and Androgen Excess and PCOS Society Disease State Clinical Review: Guide to the best practices in the evaluationa and treatment of polycystic ovary syndrome. Endocr Pract. 2015; 21: 1291-300.

43. De Leo V, Musacchio MC, Cappelli V, et al. Hormonal contraceptives: pharmacology tailored to women's health. Hum Reprod Update 2016; 22: 634-646. 